\title{
Nationalism Moh. Hatta through the Sigil Application in History Learning
}

\author{
Endah Puspita Sari, Leo Agung, Hermanu Joebagio \\ Universitas Sebelas Maret \\ pipietendahpuspita94@gmail.com
}

\section{Article History \\ accepted 1/09/2020}

approved 4/10/2020 published 1/12/2020

\begin{abstract}
Learning in schools today still uses the method of lectures and the use of Microsoft office power points. The use of teaching materials is still considered less supportive of historical learning in today's schools. Therefore, interesting and effective teaching materials are required, one of which is sigil application. This research aims to encourage the renewal of teaching materials, especially in historical learning. The approach used in this study is a qualitative method. The population used is grade XI students of IPS SMA N 1 Pacitan school year 2019/2020. The type of sample used is simple random sampling technique. Data collection techniques using polls. Based on the results of the study can be concluded: 1) Moh nationalism. Hatta was a nationalism handed over entirely to the people. 2) sigil application is one of the software applications used to create ebooks in Epub format. 3) Historical learning using sigil applications can affect students' nationalism.
\end{abstract}

Keywords: Nationalism, Moh. Hatta, Sigil application, history learning

\section{Abstrak}

Pembelajaran di sekolah saat ini masih menggunakan metode ceramah dan pengunaan microsoft office power point. Penggunaan bahan ajar tersebut masih dianggap kurang mendukung pembelajaran sejarah di sekolah saat ini. Oleh sebab itu diperlukan bahan ajar yang menarik dan efektif, salah satunya aplikasi sigil. Penelitian ini bertujuan untuk mendorong pembaruan bahan ajar khususnya dalam pembelajaran sejarah. Pendekatan yang digunakan dalam penelitian ini adalah metode kualitatif. Populasi yang digunakan yakni siswa kelas XI IPS SMA N 1 Pacitan tahun ajaran 2019/2020. Jenis sampel yang digunakan yaitu teknik simple random sampling. Teknik pengumpulan data menggunakan angket.Berdasarkan hasil penelitian dapat disimpulkan: 1) nasionalisme Moh. Hatta adalah sebuah nasionalisme diserahkan seluruhnya kepada rakyat. 2) aplikasi sigil ialah salah satu aplikasi berjenis sofware yang digunakan untuk membuat e-book dalam format Epub. 3) pembelajaran sejarah menggunakan aplikasi sigil dapat berpengaruh terhadap sikap nasionalisme siswa.

Kata Kunci: Nasionalisme, Moh. Hatta, aplikasi Sigil, pembelajaran sejarah

Social, Humanities, and Education Studies (SHEs): Conference Series

https://jurnal.uns.ac.id/shes

p-ISSN 2620-9284

e-ISSN 2620-9292 


\section{PENDAHULUAN}

Dasar pendidikan Indonesia tertulis dalam Undang-Undang Sistem Pendidikan Nasional (UU Sisdiknas) Republik Indonesia no 20 tahun 2003. Pada UU ini tercantum mengenai tujuan pendidikan Indonesia di bab II ayat 3. Secara singkat tujuan pendidikan nasional bertujuan untuk membentuk watak peradaban yang bermartabat. Oleh sebab itu mata pelajaran yang disajikan di sekolah harus memiliki nilai yang berhubungan dengan watak bermartabat.

Pembelajaran yang berbasis nilai watak bermartabat dapat dilakukan melalui pembelajaran sejarah. Pembelajaran sejarah menurut Leo Agung adalah mata pelajaran yang menumbuhkan pengetahuan, sikap, dan nilai tentang langkah perubahan dan perkembangan masyarakat Indonesia dan dunia dari masa lampau sampai masa kini (Leo Agung, 2013:55). Indikator pembelajaran sejarah berdasarkan pemikiran Djoko Suryo (2005:03) (dalam Aman, 2011:62) sebagai berikut: a) pembelajaran sejarah memiliki tujuan, substansi, dan sasaran pada segi-segi bersifat normatif, b) nilai dan makna sejarah diarahkan pada kepentingan tujuan pendidikan daripada akademik atau ilmiah murni, c) pembelajaran sejarah harus bersifat pragmatig, agar dimensi dan subtansi dipilih dan disesuaikan dengan tujuan, makna, dan nilai pendidikan yang hendak dicapai yaitu sesuai dengan tujuan pendidikan, d) pembelajaran sejarah secara normatif harus relevan dengan rumusan tujuan pendidikan nasional, e) pembelajaran sejarah harus memuat unsur pokok seperti; instruction, intellectual training, dan bertanggung jawab pada masa depan bangsa, f) pembelajaran sejarah tidak hanya memberikan mengenai pengetahuan fakta pengalaman kolektif dari masa lampau, tetapi harus memberikan latihan berpikir kritis dalam memetik makna dan nilai dari peristiwa sejarah yang dipelajari.

Sebutan untuk masa sekarang yang kita alami saat ini adalah era globalisasi. Globalisasi yaitu ketergantungan antar bangsa dan manusia di seluruh dunia melalui perdagangan, investasi, perjalanan, budaya populer, dan bentuk interaksi yang lain, sehingga hubungan antar bangsa tidak mengenal batas (Prishatuti, 2013:35 dalam Sulastri Rini Rindrayani, 2016:336).

Dampak positif dari globalisasi ialah mudahnya komunikasi antar negara, tetapi dampak negatifnya dapat menyebabkan pudarnya nilai kebangsaan. Dampak negatif ini bisa dilihat dari kebiasaan para pemuda kita lebih menyukai produk luar negeri ketimbang dalam negeri (Wuri Wuryandani,-:01).

Tujuan utama pembelajaran sejarah ialah membentuk karakter nasionalisme siswa. Pada prakteknya masih banyak pembelajaran sejarah belum dapat mencapai tujuannya, karena lebih mementingkan materi berupa fakta tanpa disisipkan nilai (S. Hamid Hasan, 2012:89).

Pembelajaran sejarah tidak harus menoton. Kita sebagai para guru harus berani berinovasi dalam pembelajaran. Salah satunya menggunakan aplikasi sigil. Sigil yakni salah satu aplikasi berjenis software yang digunakan untuk membuat e-book atau buku digital versi website (Lia Pebriani Wulandari, Ismail, dan Rita Kumalasari, 2019:65).

Pada penelitian ini aplikasi sigil digunakan untuk membantu membuat e-modul. E-modul yang akan diproduksi berupa nilai nasionalisme Moh. Hatta. Pemilihan tokoh Moh. Hatta, karena sebagian besar mengenal beliau sebagai bapak proklamator, tapi mereka belum paham apa dan bagaimana perjuangan beliau sehingga Indonesia bisa merdeka saat ini.

\section{METODE}

Metode penelitian yang digunakan dalam penelitian ini bersifat kualitatif. Jenis kualitatif yang digunakan adalah peneliti sebagai kunci instrumen. Peneliti sebagai kunci instrumen menurut John W. Cresswell (2009:175) adalah penelitian kualitatif yang datanya dikumpulkan sendiri oleh peneliti melalui pemeriksaan dokumen, observasi tingkah laku atau wawancara partisipan. Pemeriksaan dokumen dilakukan di SMA N 1 
Pacitan untuk mengecek materi sejarah, kurikulum sejarah, dan hasil belajar siswa dalam mata pelajaran sejarah. Peneliti melakukan wawancara kepada peserta didik, guru, dan kepala sekolah mengenai materi sejarah terutama tokoh Moh. Hatta dan bahan ajar yang digunakan di sekolah tersebut.

\section{HASIL DAN PEMBAHASAN}

Pada tanggal 14 Maret 1980 Dr. Moh. Hatta lahir di Bukittinggi, Sumatera Barat. Beliau pernah bersekolah di Europeeese Lagere School (ELS) tahun 1916, Meer Uitgebreid Lagere Onderwijs (MULO) Padang tahun 1919, Prins Hendrik School, dan Handels Hoogere School (Sekolah Tinggi Ekonomi) di Rotterdam Belanda tahun 1921 (Maryono, 2015:24). Selain memiliki jejak pendidikan yang cemerlang, beliau juga memiliki pengalaman organisasi yang cukup mengakumkan. Beliau pernah menjadi bendara di Jong Sumatranen Bond (JSB) Padang dan tergabung dalam perkumpulan Indische Vereniging atau Perhimpunan Indonesia.

Pengalaman organisasi ini yang melahirkan sikap nasionalisme dalam diri Moh. Hatta. Beliau sangat menjunjung tinggi rasa demokrasi. Konsep demokrasi Moh. Hatta adalah nasionalisme negara seharusnya diserahkan kepada rakyat (Bur Rasuanto, 2000:109-110).

Untuk menunjang ketercapaian sikap nasionalisme Moh. Hatta di sekolah, peneliti menggunakan aplikasi berbasis sofware yang bernama sigil. Sigil ialah sebuah aplikasi manajemen dan pembuatan digital book dengan format Epub (Nunuk Suryani, 2018:88). Pada aplikasi ini terdapat fitur tampilan buku dan kode (Zeny Dwi Martha, Eka Pramono Adi, dan Yerry Soepriyanto, 2018:113).

Penelitian mengenai sikap nasionalisme Moh. Hatta dilakukan di SMA N 1 Pacitan. Sebelumnya peneliti melakukan observasi dan wawancara terhadap pihak sekolah. Aspek yang diamati berupa perangkat proses pembelajaran, silabus, model pembelajaran, bahan ajar, media yang digunakan dan cara melakukan transfer sikap nasionalisme Moh. Hatta terhadap para peserta didik.

Materi yang digunakan untuk e-modul adalah mata pelajaran sejarah wajib kelas XI semester 1. Peneliti menggunakan Kompetesi Dasar (KD) 3.6 menganalisis peristiwa proklamasi kemerdekaan dan maknanya bagi kehidupan sosial, budaya, ekonomi, politik, dan pendidikan bangsa Indonesia dan KD 3.7 menganalisis peristiwa pembentukan pemerintah pertama Republik Indonesia dan maknanya bagi kehidupan kebangsaan Indonesia masa kini (Sardiman AM dan Amurwani Dwi Lestariningsih, 2014:07). Pada bahasan tersebut peneliti mulai menelusuri sikap nasionalisme Hatta yang demokrasi.

Setelah melakukan observasi peneliti membuat e modul menggunakan aplikasi sigil. Sebelum mendesain kita harus mendownload aplikasi sigil di laman pencarian. Kita juga perlu mempersiapkan bahan-bahan materi yang akan digunakan sebagai isi dari $e-$ modul. Materi tersebut harus berbentuk HTML. Berikut ini langkah membuat e-modul menggunakan aplikasi sigil (Direktorat Pembinaan SMA. Ditjen Pendidikan Dasar dan Menengah, 2017:19-29):

A. Buka file HTML yang dibuat ke dalam sigil. Sigil -> file -> open

B. Kolofon adalah catatan penulis yang terdapat pada akhir naskah, berisi keterangan tempat, waktu, dan penyalinan naskah. Metadata pada epub berfungsi sebagai identitas buku.

C. Conver image adalah halaman sampul dari buku digital yang kita buat. Berisi judul dan nama pengarang.

Pengembangan karakteristik nasionalisme Moh. Hatta menjadikan siswa lebih bersemangat untuk belajar sejarah. Tidak sekedar mengetahui bentuk nasionalisme Moh. Hatta tetapi mereka bisa menerapkan sikap-sikap itu dilingkungan mereka. 


\section{SIMPULAN}

Moh. Hatta adalah salah satu proklamator Indonesia. Beliau terkenal dengan karakter nasionalisme, yaitu demokrasi. Beliau menghargai pendapat orang lain dan merasa bahwa nasionalisme suatu bangsa berada di tangan rakyat bukan suatu golongan. Untuk mempermudah pemahaman siswa mengenai karakter Moh. Hatta penelitian ini menggunakan aplikasi sigil untuk membuat e-modul. Hasilnya para siswa lebih tertarik belajar sejarah menggunakan aplikasi ini dibandingkan membaca buku secara langsung.

\section{DAFTAR PUSTAKA}

Agung, Leo dan S. Wahyuni. 2013. Perencanaan Pembelajaran Sejarah. Yogyakarta: Ombak.

AM, Sardiman dan Amurwani Dwi Lestariningsih. 2014. Sejarah Indonesia: Buku Guru SMA/MA/SMK/MAK Kelas XI. Jakarta: Kementerian Pendidikan dan Kebudayaan.

Aman. 2011. Model Evaluasi Pembelajaran Sejarah. Yogyakarta: Ombak.

Cresswell, John W. (2009). Third Edition: Research Design: Qualitative, Quantitave, and Mixed Methods Approches. California: SAGE Publication, Inc.

Direktorat Pembinaan SMA. Ditjen Pendidikan Dasar dan Menengah. 2017. Panduan Praktis Penyusunan E-Modul Tahun 2017. Jakarta: Direktorat Pembinaan Sekolah Menengah Atas Direktorat Jenderal Pendidikan Dasar dan Menengah Kementerian Pendidikan dan Kebudayaan.

Rindrayani, Sulastri Rini. 2016. Upaya Membangun Guru Profesional Berkarater di Era Globalisasi Melalui Pembelajaran. Seminar PPG SM-3T UM 2016, hlm. 336.

Hamid Hasan, S. 2012. Pendidikan Sejarah untuk Memperkuat Pendidikan Karakter. Paramita, vol. 22, no. 1, hlm. 05.

Maryono. 2015. Bung Hatta, Proklamator, Ilmuwan, Penulis, dan Karya-Karyanya: Sebuah Analisis Bio-Bibliometrik. Jurnal Berkala IImu Perpustakaan dan Informasi, vol. XI, no. 2, hlm. 24.

Martha, Zeny Dwi, Eka Pramono Adi, \& Yerry Soepriyanto. 2018. Ebook Berbasis Mobile Learning. JKTP, vol. 1, no. 2, hlm. 113.

Rasuanto, Bur. 2000. Keadilan Sosial Dua Pemikiran Indonesia Soekarno dan Hatta. Wacana, vol. 2, no. 1, hlm. 109-110.

Suryani, Nunuk, I Achmad Setiawan, \& Aditin Putria. 2018. Media Pembelajaran Inovatif dan Perkembangannya. Bandung: PT Remaja Rosdakarya.

Wulandari, Lia Perbriani, Ismail, \& Rita Kumalasari. 2019. Perkembangan Bimbingan Pribadi dan Sosial Berbasis Sigil Tentang Bahaya Pornografi. Edudikara: Jurnal Pendidikan dan Pembelajaran, vol. 4, no. 1, hlm. 65. 